\title{
A IRA DO CAPITÃO-MOR: MARÇAL NUNES DA COSTA E O GOVERNO DO PARÁ NO SÉCULO XVII
}

FABIANO VILACA DOS SANTOS*

UNIVERSIDADE DO ESTADO DO RIO DE JANEIRO

RIO DE JANEIRO - RIO DE JANEIRO - BRASIL

Este artigo apresenta resultados parciais de pesquisa sobre o governo do Pará, no século XVII, tendo por base as críticas de Marçal Nunes da Costa à usurpação da sua jurisdição e de outros capitães-mores pelos governadores e capitães-generais do Estado do Maranhão, bem como os conflitos entre esses agentes. O texto analisa, portanto, a dinâmica política e administrativa nesta circunscrição, envolvendo, principalmente, capitães-mores do Pará e governadores, mas também a Câmara de Belém. Discutindo questões como: a existência e o respeito aos regimentos; a delegação de poderes e jurisdições pelos reis de Portugal aos governantes ultramarinos; a fragilidade da autoridade dos capitães-mores do Pará frente aos interesses particulares e à

RESUMO articulação dos poderes locais, por intermédio da Câmara, com os governadores e capitães-generais. A metodologia empregada para subsidiar as conclusões apresentadas consistiu, basicamente, na análise qualitativa de correspondências oficiais dos capitães-mores com autoridades em Lisboa, regimentos para os governos do Pará e do Estado do Maranhão, cartas patentes e, no cotejo destas fontes, com informações contidas em obras de referência sobre a história política e administrativa local.

Palavras-chave: Marçal Nunes da Costa; Governo do Pará; Conflitos de jurisdição.

This article presents partial results of research on the government of Pará, in the 17th century, based on the criticisms of Marçal Nunes da Costa to the usurpation of his jurisdiction and that of other captains majors by the governors and captains generals of the State of Maranhão, as well as conflicts between these agents. The text therefore analyzes the political and administrative dynamics in this constituency, involving, mainly, captains majors of Pará and governors, but also the Chamber of Belém, discussing issues such as: the existence and respect for the rulegements; the delegation of powers and jurisdictions by the kings of Portugal to the colonial administrators; the ABSTRACT fragility of the authority of the captains-mores of Pará vis-à-vis private interests and the articulation of local powers, through the Chamber, with the governors and captains generals. The methodology used to support the conclusions presented consisted, basically, in the qualitative analysis of official correspondence of the captains-mores with authorities in Lisbon, of regiments for the governments of Pará and the State of Maranhão, of patent letters and, in the comparison of these sources, with information contained in works reference on local political and administrative history.

Keywords: Marçal Nunes da Costa; Government of Pará; Jurisdiction conflicts.

\footnotetext{
* Doutor em História pela Universidade de São Paulo (USP). Professor da Universidade do Estado do Rio de Janeiro (UERJ) e Inves tigador colaborador do Centro de História da Universidade de Lisboa. E-mail: fabianovilaca @ gmail.com.
} 


\section{INTRODUCÃO'}

Em 1662, o ouvidor Maurício de Heriarte fez a seguinte descrição de Belém: "tem esta cidade uma fortaleza sobre o porto, bastante defendida com três companhias de infantaria, tem capitão-mor, ouvidor, provedor, almoxarife e escrivão real, que tudo se sustenta da fazenda de Sua Majestade". ${ }^{2}$ Naquele ano, D. Pedro de Melo (1658-1662) encerrava o governo do Estado do Maranhão e Grão-Pará e, em pouco tempo, o entregaria a Rui Vaz de Siqueira (1662-1667). Àquela altura, os governadores e capitães-generais não se deslocavam sistematicamente para Belém nem lá se fixavam, como a partir de 1672/73. Faziam-no eventualmente, desde o primeiro governador e capitão-general, Francisco Coelho de Carvalho (1626-1636), até Antônio de Albuquerque Coelho de Carvalho, o velho (1667-1671). Rui Vaz de Siqueira, inclusive, teria inaugurado um ritual solene de entrada em Belém, justamente à época em que Marçal Nunes da Costa terminava seu primeiro governo no Pará (1658-1662). ${ }^{3}$

Este capitão-mor presenciou os tumultos dos moradores que levaram à expulsão dos jesuítas, em 1661, mas não a sua volta no ano seguinte, no tempo do seu sucessor, Francisco de Seixas Pinto, que sofreu diretamente os efeitos dessa conjuntura. A impressão transmitida pela narrativa de Heriarte de que o aparato administrativo e defensivo de Belém estava em perfeita ordem contrastava, portanto, com o ambiente turbulento na cidade. Mas, independentemente da expulsão dos jesuítas, já existiam animosidades entre capitães-mores do Pará e governadores e capitães-generais do Estado do Maranhão. E continuaram existindo. Em sua segunda passagem pela capitania-mor (1674-1685), um iracundo Marçal Nunes da Costa denunciou a usurpação dos seus poderes e jurisdições pelos seus superiores, instalados em Belém, além de algumas vantagens que o posto lhe conferia, relembrando antigos casos em que antecessores haviam sido violenta e arbitrariamente suspensos de suas funções por diferentes governadores e capitães-generais.

\footnotetext{
${ }^{1}$ Este artigo resulta de investigações do autor que recuam ao Pará e ao Maranhão seiscentistas, como desdobramentos de pesquisas situadas no século XVIII sobre a história administrativa e as trajetórias dos governadores e capitães-generais do Estado do Maranhão, também com avanços para o século XIX. Tais iniciativas têm recebido apoio da UERJ e da FAPERJ, na forma de bolsas de Iniciação Científica. Agradeço a Rafael Chambouleyron a leitura atenta e os comentários que muito contribuíram para o aprimoramento do texto.

${ }^{2}$ HERIARTE, M. de [1662]. Descripção do Estado do Maranhão, Pará, Corupá e Rio das Amazonas. Vienna d'Áustria: Imprensa do filho de Carlos Gerold, 1874, p. 23.

${ }^{3}$ BAENA, A. L. M. Compêndio das eras da província do Pará. Belém: Typographia de Santos \& Santos Menor, 1838, p. 109-110. SANTOS, F. V. dos. Entre São Luís e Belém: um estudo da dinâmica de governo no Estado do Maranhão e Grão-Pará (1673-1751). In: BORGES, E. J. S.; FLEXOR, M. H. O.; SEVERS, S. M. de S. S. (Org.). Poderes, identidades e sociedade na América portuguesa (séculos XVI-XVIII). São Paulo: Alameda, 2017, p. 163-188.
} 
Na visão de Marçal Nunes da Costa, como deixam entrever suas queixas, se o rei era a fonte do poder e da jurisdição delegados aos seus representantes no desempenho da governação, somente ele dispunha de autoridade legítima para destituí-los. Essa "jurisdição delegada" pelos monarcas portugueses era, segundo António Manuel Hespanha, um dos elementos de que se revestia o poder imperial (Imperium) nas monarquias modernas. Suas conquistas ultramarinas, consideradas províncias, compunham o Império. Apesar da descontinuidade territorial e das diferenças de organização, tais comunidades políticas respondiam a um poder superior (imperial) que, por sua vez, também precisava reconhecer e se adaptar às especificidades locais. ${ }^{4}$ A complexidade desse processo parece escapar ao entendimento mesmo de homens experimentados nas guerras de conquista e na defesa de territórios além-mar. Como Marçal Nunes da Costa, que procurou defender os princípios de sua autoridade como administrador colonial, nos termos da delegação do poder régio consignada em sua carta patente e regimento, desprezando as injunções políticas em sua jurisdição.

Por outro lado, a compreensão dessa dinâmica, muitas vezes conflituosa, de conquista e colonização, que envolvia diferentes atores sociais e políticos, tais como, conquistadores, oficiais régios, principais da terra, câmaras e etc., dotados de atribuições e interesses ora convergentes, ora divergentes, pode se beneficiar de uma aproximação das ideias de que "fazer a história da divisão político-administrativa é fazer a história das relações entre o poder e o espaço" e de que "a divisão política do espaço constitui também um instrumento de poder", que propiciava ao mesmo tempo o estabelecimento e a consolidação de grupos sociais em determinado espaço e o alijamento de concorrentes. ${ }^{5}$ Essas noções estavam presentes, em alguma medida, na prática cotidiana do poder no Pará seiscentista, interferindo diretamente nas relações entre capitães-mores, governadores e poderes locais, em um "território" - entendido como a "apropriação do espaço" e "transformado historicamente pelas sociedades" contornos geográficos, políticos, sociais, econômicos e culturais em construção.

O objetivo deste artigo é pontuar conflitos de jurisdição entre capitães-mores do Pará e governadores do Estado do Maranhão, no século XVII, tendo como ponto de partida as queixas

\footnotetext{
${ }^{4}$ HESPANHA, A. M. Como os juristas viam o mundo, 1550-1750. Direitos, estados, pessoas, coisas, contratos, ações e crimes. Lisboa: Create Space Independent Publishing Platform, 2015, p. 37-42 e p. 220.

${ }^{5}$ HESPANHA, A. M. As vésperas do Leviathan. Instituições e poder político, Portugal - séc. XVII. Coimbra: Livraria Almedina, 1994, p. 8587.

${ }^{6}$ SOUZA, M. L. de. "Território" da divergência (e da confusão). Em torno das imprecisas fronteiras de um conceito fundamental. In: SAQUET, M. A.; SPOSITO, E. S. (Org.). Territórios e territorialidades: teorias, processos e conflitos. $2^{\mathrm{a}}$ ed. Rio de Janeiro: Consequência, 2015, p. 7079.
} 
de Marçal Nunes da Costa contra a usurpação de sua jurisdição. As principais hipóteses para a existência de tais conflitos são a ausência de um instrumento normativo e ordenador (Regimento) dos poderes dos capitães-mores do Pará, e a dinâmica administrativa que se instalou no Estado do Maranhão nos idos de 1670, caracterizada pela itinerância do governo e a fixação dos governadores em Belém. Na primeira parte do texto, fez-se um panorama da organização político-administrativa da capitania-mor do Pará, no século XVII, seguindo-se uma exposição do Regimento dos capitães-mores, de 1669, e, finalmente, das denúncias de Marçal Nunes da Costa, que ensejaram uma análise retrospectiva de questões de autoridade envolvendo as duas principais hierarquias governativas do Estado do Maranhão.

\section{A CAPITANIA-MOR DO PARÁ NO SÉCULO XVII}

No princípio do século XVIII, Raphael Bluteau definiu capitania como um "cargo militar" ou "ofício de capitão" e "capitanear" como "fazer o ofício de capitão". 7 Os dois verbetes não remetiam a um espaço geográfico delimitado por uma circunscrição administrativa, mas ao desempenho de um ofício essencialmente militar, a capitania ou capitania-mor, uma função de comando. O termo capitania-mor remonta em Portugal aos séculos XIV/XV, na fase da expansão marítima para o Norte da África, e relacionava-se ao ofício de capitão-mor da frota real. Era, portanto, uma função anterior às capitanias-mores do Oriente, sendo o capitão-mor da frota lugar-tenente do almirante e podendo substituí-lo com todas as prerrogativas no comando de uma armada. ${ }^{8}$

No século XIX, Varnhagen definiu os capitães-mores "como agentes subalternos do governador e como seus verdadeiros delegados militares, e até certo ponto administrativos, nas capitanias de menos conta e nas vilas". ${ }^{9}$ Essa delegação já transparecia nas instruções dadas por Gaspar de Sousa, governador-geral do Estado do Brasil, a Alexandre de Moura, a quem delegara poderes para empreender a conquista do Maranhão aos franceses, repassados a Francisco Caldeira de Castelo Branco, em 1615, na forma de um Regimento que o instruiu a partir de São Luís, correr a costa até entrar no rio Pará, escolher um local apropriado para erguer

\footnotetext{
${ }^{7}$ BLUTEAU, R. Vocabulario portuguez \& latino. Coimbra: Collegio das Artes da Companhia de Jesu, 1712, vol. 2, p. 125-126.

${ }^{8}$ PEREIRA, C. A. L. A Capitania-mor do Mar da Índia (1502-1564). Dissertação de Mestrado. Lisboa/PT: Faculdade de Ciências Sociais e Humanas, Universidade Nova de Lisboa, 2016, p. 10-13.

9 VARNHAGEN, F. A. de. História Geral do Brazil. Rio de Janeiro: E. H. Laemmert, 1857, tomo II, p. 79.
} 
uma fortificação (o Forte do Presépio ou do Castelo) e armá-la com as 10 peças de artilharia que transportava, além de promover a redução do gentio no entorno do núcleo original da cidade de Belém. ${ }^{10}$

Francisco Caldeira de Castelo Branco foi sucedido na capitania do Pará por vários militares, de 1618, quando foi deposto e preso, até 1626. O Estado do Maranhão (tendo o Pará como capitania subalterna) havia sido criado por decreto de 13 de junho de 1621, separado da jurisdição do Governo-geral do Brasil, mas seu primeiro governador e capitão-general, Francisco Coelho de Carvalho, só assumiu em 1626, estando nomeado desde $1623 .{ }^{11} \mathrm{Na}$ sua companhia veio Manuel de Sousa de Eça, provido na "capitania do presídio da conquista do Pará”, segundo o alvará de 12 de dezembro de $1621^{12}$, que estabelecia o seu soldo, deixando entrever que a carta patente de nomeação era anterior. A esta altura, Bento Maciel Parente capitaneava em Belém, provido pelo governador-geral do Brasil, D. Luís de Sousa, no mesmo ano de $1621 .^{13}$

O açoriano Manuel de Sousa de Eça, cavaleiro do hábito de Santiago, havia participado, assim como Bento Maciel Parente, da conquista do Maranhão, tendo sido ambos agraciados com a mercê da capitania-mor do presídio do Pará - uma alusão à conquista recente do território pela monarquia filipina - pelo largo conhecimento dos rios da região, por onde ingleses, franceses e holandeses praticavam comércio, do trato com os índios e do potencial de riquezas naturais, como as madeiras, conforme os memoriais que produziram e enviaram ao governo de Madri com propostas, por exemplo, de integrar o Maranhão ao circuito da prata peruana. $\mathrm{Na}$ sucessão de Manuel de Sousa de Eça despontou outro explorador do Amazonas e defensor da introdução da prata de Potosí pelo rio, Luís Aranha de Vasconcelos ${ }^{14}$, cavaleiro do hábito de

\footnotetext{
10 SARAGOÇA, L. Da "Feliz Lusitânia” aos confins da Amazônia (1615-1662). Lisboa: Edições Cosmos; Câmara Municipal de Santarém, 2000, p. 226-227. AMARAL, J. R. do. Fundação de Belém do Pará: jornada de Francisco Caldeira de Castelo Branco, em 1615-1616. Brasília: Edições do Senado Federal, 2004, p. 43-45. A transcrição do Regimento de Francisco Caldeira de Castelo Branco publicada no livro de José Ribeiro do Amaral contém alguns erros. Para uma análise atualizada dessas instruções, ver CORRÊA, H. M. M. "Para aumento da conquista e bom governo dos moradores": o papel da Câmara de São Luís na conquista, defesa e organização do território do Maranhão (1615-1668). Tese (Doutorado em História) Programa de Pós-graduação em História Social, Universidade Federal Fluminense, Niterói, 2011 , p. $94-102$. ${ }^{11}$ BERREDO, B. P. de [1749]. Annaes historicos do Estado do Maranhão, em que se dá notícia do seu descobrimento, e tudo o mais que nelle tem succedido desde o anno em que foy descuberto até o de 1718. 2 ed. São Luiz: Typographia Maranhense, 1849, tomo I, p. 236. Foi efetivamente o primeiro governador, apesar da nomeação por Filipe III, de D. Diego de Cárcamo (ou Diogo, como também é grafado), que nunca assumiu. Ver CARDOSO, A. C. Maranhão na monarquia hispânica: intercâmbios, guerra e navegação nas fronteiras das Índias de Castela (1580-1655). Tese (Doutorado), Facultad de Geografía e Historia, Departamento de Historia Medieval, Moderna, Contemporánea y de América, Universidad de Salamanca, Salamanca, 2012, p. 152-155.

${ }^{12}$ Arquivo Nacional da Torre do Tombo [ANTT]. Chancelaria de Filipe III. Doações. Livro 18, fl. 224v.

13 SARAGOÇA, L. Da "Feliz Lusitânia" aos confins da Amazônia (1615-1662). Lisboa: Edições Cosmos; Câmara Municipal de Santarém, 2000 , p. 35.

${ }^{14}$ Sobre a atuação de Manuel de Sousa de Eça, Bento Maciel Parente e Luís Aranha de Vasconcelos nos primórdios da conquista do Maranhão e do Pará, ver CARDOSO, A. C., 2012, p. 68, 164-167 e 202-212.
} 
Cristo, que chegou a Belém em maio de 1623 e recebeu a "mercê da capitania da fortaleza do Pará", por carta patente de 20 de novembro de 1624, devendo assumi-la "na vagante de Manuel de Eça que de presente a está servindo". ${ }^{15}$ A “vagante dos providos" - uma prática que consistia na nomeação de um indivíduo para um posto ainda ocupado por outrem, abolida na década de 1650, - foi recorrente nos provimentos de capitães-mores do Pará nos primórdios da sua organização política e administrativa. ${ }^{16}$ Em resumo, provido em 1621, Manuel de Sousa de Eça só assumiu a capitania do Pará em 1626 (nesse ínterim, Bento Maciel Parente, nomeado por D. Luís de Sousa também em 1621, a governava) e Luís Aranha de Vasconcelos, que estava em Belém, desde 1623, e recebeu carta patente do cargo no ano seguinte, só pôde tomar posse depois que Manuel de Sousa de Eça concluiu seu triênio, em 1629.

Conflitos com a Câmara e os governadores do Estado do Maranhão resultaram em suspensões, deposições e prisões de capitães-mores, conferindo uma aparente instabilidade ao exercício do cargo. Porém, evidenciaram as adversidades e acomodações decorrentes do processo de ocupação e de colonização das terras do Norte, com suas dinâmicas de exploração e o enraizamento dos interesses daqueles que participaram e sustentaram a conquista do Maranhão. No início do século XVII, segundo Guida Marques, este projeto recebeu prioridade por parte das Coroas ibéricas. Envolveu autoridades coloniais e exploradores, dotados de grandes poderes para preparar e conduzir expedições militares, cujo sucesso levou à distribuição e à ocupação das terras conquistadas, à implantação de estruturas de governo e à sua separação definitiva do Estado do Brasil com o advento, em 1621, de uma nova circunscrição política e administrativa: o Estado do Maranhão e Grão-Pará. ${ }^{17}$

$\mathrm{Na}$ prática, essa separação só ocorreu quando Francisco Coelho de Carvalho tomou posse em São Luís, como "governador e capitão geral do Maranhão e Pará”, com a atribuição da "governança e capitania-mor" do Estado. ${ }^{18}$ Ou seja, sua carta patente conferia-lhe, por delegação régia, poderes superiores para exercer o governo político e o comando militar em toda a sua jurisdição, incluindo a capitania do Pará, cujo capitão-mor passaria a estar, a partir de então, subordinado à autoridade do governador e capitão-general. Outro aspecto a ressaltar

\footnotetext{
15 ANTT. Chancelaria de Filipe III. Doações. Livro 18, fls. 304v-305.

${ }^{16}$ ROCHA, R. A. A elite militar no Estado do Maranhão: poder, hierarquia e comunidades indígenas (século XVII). Tese (Doutorado em História), Programa de Pós-graduação em História Social, Universidade Federal Fluminense, Niterói, 2013, p. 33-35.

${ }_{17}$ MARQUES, G. Entre deux empires: le Maranhão dans l’Union Ibérique (1614-1641). Nuevo Mundo Mundos Nuevos. Débats, 2010, p. 6. Disponível em: <http://journals.openedition.org/nuevomundo/59333〉. Acesso em: jan. 2021.

18 ANTT. Chancelaria de Filipe III. Doações. Livro 18, fls. 154v-155.
} 
é que o capítulo 58 do Regimento de Francisco Coelho de Carvalho ${ }^{19}$, o primeiro para o governo do Estado do Maranhão, e o capítulo 31 do Regimento dos governadores e capitães-generais do Estado do Maranhão e Grão-Pará, de 14 de abril de 1655, passado a André Vidal de Negreiros, alvo de contestações por parte dos capitães-mores do Pará, como será visto adiante, eram praticamente iguais, com pouquíssima diferença na redação. ${ }^{20}$ Ambos versavam justamente sobre o poder dos governadores e capitães-generais para emprazar e suspender os capitãesmores do Pará e nomear interinos.

A semelhança dos capítulos corrobora as conclusões de Helidacy Corrêa de que os regimentos anteriores de Pedro de Albuquerque e de Luís de Magalhães serviram de modelo para o de André Vidal de Negreiros, conforme a consulta do Conselho Ultramarino de 11 de janeiro de $1655 .^{21}$ Por sua vez, o capítulo 58 do Regimento de Francisco Coelho de Carvalho parece ter se mantido quase inalterado por anos, até 1655, ao contrário de outros mencionados na consulta, como os capítulos 10, 18, 22, 24 e 27, integralmente suprimidos, ou 9, 21, 23, 25 e 32, que sofreram alguma redução ou ajuste no texto, de modo que o novo Regimento estivesse pronto à altura do embarque de André Vidal de Negreiros. ${ }^{22}$

Para efeito da discussão que ora se desenvolve, importa destacar que a manutenção da prerrogativa regimental dos governadores de afastar do cargo os capitães-mores do Pará, para além de reiterar a subordinação destes aos primeiros, gerou grande instabilidade no governo da capitania durante boa parte do século XVII. Isso se refletiu, em meados da centúria, nas considerações do Conselho Ultramarino sobre a divisão do Estado. Um caso que pode ter ajudado a constituir uma memória dos imbróglios políticos e administrativos locais e a subsidiar a decisão de D. João IV pela separação do Maranhão e do Pará em governos distintos, entre 1652 e 1654, ocorreu quando Bento Maciel Parente, alçado a governador e capitão-general, emprazou $^{23}$ e suspendeu das suas funções o capitão-mor Manuel Madeira.

\footnotetext{
${ }^{19}$ Biblioteca Nacional de Portugal. Reservados. Fundo Geral de Manuscritos. Cód. 7627, fl. 145.

${ }^{20}$ Arquivo Histórico Ultramarino [AHU]. Cód. 169, fl. 120v.

${ }^{21}$ CORRÊA, 2011, p. 94-154. A autora considera também o Regimento passado por Alexandre de Moura a Jerônimo de Albuquerque, em 1616, nomeado capitão-mor do Maranhão subordinado ao Governo-Geral do Estado do Brasil. Para efeito desta análise, parte-se do Regimento do primeiro governador do Estado do Maranhão, Francisco Coelho de Carvalho (1626-1636).

${ }^{22}$ AHU. Consultas Mistas. Cód. 15, fls. 142v-143. Agradeço a Hugo André Flores Fernandes Araújo a gentileza de me indicar este documento e ceder a sua transcrição.

23 "Emprazar" significa citar alguém por intermédio de uma instância superior da Justiça - neste caso, o ouvidor - para que tome ciência da razão de uma queixa e responda à citação em um prazo estabelecido. BLUTEAU, 1712-1720, vol. 3, p. 68.
} 
Manuel Madeira foi um daqueles capitães nomeados na "vagante dos providos", na primeira metade do século XVII, por carta patente de 26 de novembro de $1638 .{ }^{24}$ Veio disposto a desempenhar suas funções sem a interferência direta do governador do Estado, que tomara posse em 27 de janeiro daquele ano, conforme uma carta enviada ao rei antes mesmo de partir de Lisboa. Nela pedia que se escrevesse a Bento Maciel Parente ordenando-lhe que "não se intrometa no socorro que leva para a fortaleza do Pará assim [de] munições, armas, soldados e mais oficiais da gente que leva por ser tudo para a dita fortaleza e Vossa Majestade o mandar assim". Madeira acreditava que o governador podia querer lhe "tomar alguma cousa do socorro que leva para prover outras partes" 25 , por uma questão hierárquica, e talvez, por saber que Bento Maciel Parente representara dois anos antes a Filipe III sobre a situação do Estado do Maranhão, denunciando a precariedade das suas defesas pela falta de homens, de armas, de munições e pagamentos havia mais de sete anos, e solicitando o envio de diversos apetrechos de guerra. ${ }^{26}$

A disposição de Manuel Madeira de manter sua jurisdição sobre a fortaleza e o governo das armas do Pará sem a intromissão do governador do Estado, ao que parece, acabou por se transformar na causa da sua ruína. Não demorou muito e mal explicadas "queixas de ter o capitão-mor traspassado as linhas e os limites da sua autoridade", possivelmente endereçadas pelos moradores de Belém, chegaram ao conhecimento de Bento Maciel, que suspendeu Madeira de suas funções. ${ }^{27}$ Nestes casos, os governadores proviam no cargo indivíduos da sua confiança e parentela, em geral pessoas que participaram diretamente da conquista do território ou descendiam dos primeiros conquistadores, tinham representação nos órgãos de poder local - as Câmaras de Belém e de São Luís - e/ou ocupavam postos na administração. ${ }^{28}$

Foi assim que Bento Maciel Parente resolveu a sucessão de Manuel Madeira. Em cerca de um ano, entre 1640 e 1641, três indivíduos ligados ao governador se revezaram na capitania do Pará: Pedro Teixeira, substituído em pouco tempo pelo provedor da Fazenda Francisco Cordovil Camacho, aparentado do governador. ${ }^{29}$ Doente, entregou seus poderes à Câmara de Belém e ao falecer foi rendido por ela. Meses depois, Pedro Maciel Parente, sobrinho de Bento

\footnotetext{
${ }^{24}$ ANTT. Chancelaria de Filipe III. Doações. Livro 28, fls. 136v-137.

${ }^{25}$ AHU. Projeto Resgate. Pará (avulsos). Cx. 1, D. 43.

${ }^{26}$ STUDART, Guilherme (barão de). Documentos para a história do Brasil e especialmente a do Ceará. Revista do Instituto do Ceará. Fortaleza, t. XXXIV, 1920, p. 268-271. (Documento n. ${ }^{\circ} 241$ ).

${ }^{27}$ BAENA, 1838, p. 109-110.

${ }^{28}$ BICALHO, M. F.; MONTEIRO, N. G. As instituições civis da monarquia portuguesa na Idade Moderna: centro e periferia do império. In: XAVIER, A. B.; PALOMO, F.; STUMPF, R. (Orgs.). Monarquias ibéricas em perspectiva comparada (sécs. XVI-XVIII): dinâmicas imperiais e circulação de modelos administrativos. Lisboa: ICS, 2018, p. 220.

${ }^{29}$ BAENA, 1838, p. 47-50. BERREDO, B. P. de [1749]. Annaes historicos do Estado do Maranhão..., tomo II, p. 314-319.
} 
Maciel, que recebeu patente de capitão-mor de 30 de dezembro de $1640^{30}$, enfrentou a oposição da Câmara, que se recusou a lhe dar posse quando chegou de Portugal com socorros para defender o Maranhão dos holandeses, por divergir do modo como organizou o combate aos invasores. Além deste episódio, no século XVII, principalmente, a Câmara de Belém também assumiu o governo político da capitania por vacância do cargo de capitão-mor ou por destituição do seu ocupante, elegendo em alguns um substituto. ${ }^{31}$ Formas de atuação distintas se verificavam em outras partes do Império, em que a diversidade espacial ditava o modo pelo qual os concelhos municipais agiam frente às questões da política e do governo local, a exemplo dos arquipélagos de Cabo Verde e de São Tomé e Príncipe ou da vila de Santa Maria Madalena da Lagoa do Sul, em Pernambuco, nos séculos XVII e XVIII. ${ }^{32}$

Suspender um capitão-mor no Pará e fazer a sua sucessão provendo familiares ou parciais, não foram atos exclusivos de Bento Maciel Parente nem passaram despercebidos no Reino. Por volta de 1650, foi discutida no Conselho Ultramarino a separação das capitanias do Pará e do Maranhão, em que cada qual seria governada por um capitão-mor, em lugar de haver um governador e capitão-general em São Luís e um capitão-mor subalterno em Belém:

[...] depois que houve governadores naquele Estado [a partir de Francisco Coelho de Carvalho], não houve capitão-mor que acabasse seu tempo no Pará, ou para melhor dizer que lho deixassem eles acabar, e em tempo do primeiro governador em um ano houve sete capitães-mores no Pará do que se deve presumir ou que todos os capitães-mores são maus, ou que todos os governadores o foram. E o motivo que os governadores tinham para perseguirem tanto aos capitães-mores do Pará, e suposto todos os que vieram emprazados, e culpados a este Reino, os vemos logo dar por soltos e livres, manifestamente se conhece que da ambição e cobiça, os move a semelhantes desaforos. Porque como a capitania-mor do Pará tem opinião de mais opulenta desejando-a os ditos governadores para si, com qualquer frívola ocasião os descompõem, prendem ou emprazam, e pondo em seu lugar pessoas de sua facção, vem a conseguir o que diziam, e estando isto assim,

\footnotetext{
${ }^{30}$ ANTT. Registro Geral de Mercês. D. João IV. Livro 4, fls. 246v-249.

${ }^{31}$ BAENA, A. L. M. [1833] Ensaio corográfico sobre a província do Pará. Brasília: Edições do Senado Federal, 2010 , p. 411-415.

32 RODRIGUES, J. D. O poder municipal do Antigo Regime ao Liberalismo: da autonomia jurisdicional às Juntas Gerais. Actas do Congresso $1^{\circ}$ Centenário da Autonomia dos Açores. Ponta Delgada, Jornal de Cultura, 1995, vol. 1, p. 103-126. CURVELO, A. A. S. de C. O Senado da Câmara de Alagoas do Sul: governança e poder local no Sul de Pernambuco (1654-1751). Dissertação (Mestrado em História), Programa de Pós-graduação em História, Universidade Federal de Pernambuco, Recife, 2014. Ver também BICALHO; MONTEIRO, 2018 p. $218-223$.
} 
que o que governa de presente tratou sempre mais do referido, que de reparar as fortificações que estão desfeitas [...] em as quais dizem não pôs uma só pedra até agora. $^{33}$

Para os conselheiros, a cobiça por poder e riquezas era o que movia os governadores do Estado do Maranhão a perseguir e a depor os capitães-mores do Pará. Belém ficava às portas dos sertões, que àquela altura, no tempo do governador Luís de Magalhães (1649-1652), já despertavam a atenção das autoridades para a extração de gêneros da floresta (as drogas do sertão), próximo da Fortaleza do Gurupá, no interior da capitania. Em 1648, o sargento-mor Felipe da Fonseca e Gouvêa noticiou a Lisboa a existência de muito cravo de boa qualidade e de noz-moscada no local e, dois anos depois, o próprio Luís de Magalhães deu conta do descobrimento de salsaparrilha "por cima do Gurupá". 34

Além das drogas, era preciso garantir o acesso aos índios, muitas vezes resgatados nos sertões ao arrepio da lei e escravizados nas terras de gente envolvida na governança, tanto do Maranhão quanto do Pará. Distante trinta léguas ao sul de Belém, de acordo com a Crônica do padre Bettendorff, ficava a capitania donatária de Cametá, doada em 1633 a Feliciano Coelho de Carvalho, filho do governador Francisco Coelho de Carvalho, enquanto "defronte da capitania do Gurupá”, do lado oposto do rio Amazonas, localizava-se a capitania donatária do Cabo do Norte, doada a Bento Maciel Parente em 1637. ${ }^{35}$ Não admira que estes homens da governança, com interesses particulares bem assentados no território do Estado do Maranhão, quisessem manter o controle da política e da administração no Pará, retirando da capitania-mor aqueles que de algum modo os desagradavam e colocando em seu lugar gente também enraizada na terra - "homens bons", como Feliciano Correia e Aires de Sousa Chichorro, várias vezes providos interinamente e por diferentes governadores e capitães-generais. ${ }^{36}$

As notícias que corriam sobre a divisão do Estado do Maranhão e Grão-Pará em dois governos distintos e independentes entre si causaram alvoroço na Câmara de São Luís. De início, segundo Helidacy Corrêa, a municipalidade questionou com veemência a medida,

\footnotetext{
${ }^{33}$ AHU. Projeto Resgate. Maranhão (avulsos). Cx. 1, D. 94.

${ }^{34}$ AHU. Projeto Resgate. Maranhão (avulsos). Cx. 3, D. 265 e D. 291.

${ }^{35}$ BETTENDORFF, J. F. [1698] Crônica da missão dos padres da Companhia de Jesus no Estado do Maranhão. Brasília: Edições do Senado Federal, 2010, p. 28-34. CRUZ, E. História de Belém. Belém: Universidade Federal do Pará, 1973, vol. I, p. 131-132.

${ }^{36}$ BAENA, A. L. M. [1833], 2010, p. 411-417.
} 
ameaçando descumpri-la caso fosse adotada, em defesa do sistema do governo-geral vigente havia cerca de três décadas. Porém, aos poucos os camaristas cederam aos argumentos da negociação com a Coroa, procurando convencer as autoridades no Reino de que a divisão traria prejuízos, por exemplo, à arrecadação dos dízimos, e comprometeria a defesa do território, enfraquecendo as duas capitanias, cada qual tendo que prover a sua própria segurança. $\mathrm{Na}$ verdade, a Câmara de São Luís exigia ser ouvida pelo rei e continuar sendo a principal do Estado, que deveria permanecer unificado, tendo por cabeça a cidade de São Luís, centro político-administrativo personificado na figura do governador e capitão-general. ${ }^{37}$

Não é de admirar, portanto, que Antônio de Albuquerque, da família Coelho de Carvalho, protestasse contra a divisão do Estado, na qualidade de procurador do Maranhão, defendendo a unidade e a permanência dos governadores. Sua representação ao rei, contudo, foi incapaz de demover o Conselho Ultramarino da ideia de separação das duas capitanias: "Em todo este largo papel se não diz cousa de novo, nem se dá razão que obrigue ao Conselho a mudar de parecer". Contrariando os argumentos de Antônio de Albuquerque sobre a defesa do território, o órgão advogou a favor da experiência da divisão, em que o Maranhão e o Pará retornariam à fase inicial da conquista, quando não havia entre elas uma hierarquia de capitania principal e subalterna, cada uma era governada e conheceram verdadeiros aumentos. Ou seja, o argumento da ruína apregoado pelos defensores da unidade foi totalmente refutado pelo Conselho Ultramarino, prevalecendo o seu parecer sobre a divisão, adotada de 1652 a 1654, sobrepondo-se aos protestos da Câmara de São Luís e de Antônio de Albuquerque. ${ }^{38}$

A análise desse episódio fica comprometida pela falta de documentação da Câmara de Belém. Essa é uma das razões de a historiografia não poder elucidar a questão da separação das capitanias sob o ponto de vista da edilidade, bem como a decisão de D. João IV de recompor as feições político-administrativas do Estado do Maranhão, em 1654/55, sob André Vidal de Negreiros (1655-1656). Munido de um novo Regimento para os governadores e capitãesgenerais, deu início a uma nova fase da governação. Por outro lado, os capitães-mores do Pará voltaram a ser subordinados e continuaram sem um instrumento próprio que definisse a sua jurisdição.

\footnotetext{
${ }^{37}$ CORRÊA, 2011, p. 89-93.

${ }^{38}$ AHU. Consultas Mistas. Cód. 14, fls. 348v-349; Cód. 15, fl. 1v. Agradeço a Hugo André Flores Fernandes Araújo a gentileza de me indicar estes documentos e ceder a sua transcrição.
} 
Foi nesse contexto de mudanças, ou melhor seria dizer, de um retorno à hierarquia entre os espaços políticos que compunham o Estado, que Marçal Nunes da Costa assumiu pela primeira vez a capitania-mor do Pará. Cavaleiro da Ordem de Cristo, tinha vasta experiência militar na Europa e no ultramar, tendo servido em armadas na costa do Reino e enviadas a Cádiz e a América, bem como nas guerras da Restauração portuguesa, quando esteve preso e fugiu de Castela (1640), participou do cerco ao marquês de Torreclusa, em Elvas (1644), cruzou a fronteira de Espanha na companhia do conde de Vila Franca (1645) e combateu os holandeses no Recife (1649). Foi ainda capitão de infantaria e, em 1653, correu novamente a costa de Portugal como capitão de mar e guerra de uma armada. ${ }^{39}$

Segundo os Anais de Bernardo Pereira de Berredo, chegou ao Maranhão na companhia do governador D. Pedro de Melo (1658-1662) e depois de receber suas ordens rumou para Belém, onde chegou em 24 de julho de 1658 e tomou posse em 19 de setembro, o que por motivos pouco claros, a não ser "pelas razões forçosas que o obrigavam a dilatá-la" - talvez os seus "modos escabrosos" -, o governador tentou retardar escrevendo à Câmara para que não empossasse o capitão-mor. ${ }^{40}$ Serviu em um momento delicado, quando as relações entre moradores e jesuítas em torno da escravidão indígena culminaram na primeira expulsão dos missionários do Estado do Maranhão, em 1661. Porém, além de não ter sido localizada documentação que esclarecesse a participação de Marçal Nunes da Costa no episódio, não é o propósito discuti-la nestas páginas.

Sabe-se, contudo, que saiu livre de culpas na residência que lhe foi tirada ao fim do governo, em 1662. Foi, antes, louvado por granjear a satisfação dos moradores e proceder com retidão, sendo homem pobre e de exemplar costume, que na ocasião do motim e expulsão dos padres da Companhia de Jesus sofreu perseguições e "padeceu grandes trabalhos" e injúrias. Mesmo assim, na "rebelião do povo", portou-se de "tal modo que não houve em tais dias fatais como estes nenhuma morte, ferimento e roubo, que sucedesse que em semelhantes sedições e motins sempre sucede nas repúblicas, fazendo e sendo com a paciência que teve que fez mais do que podia com sua grande vigilância e cuidado". ${ }^{41}$ Por isso, estava apto a receber as mercês com as quais a monarquia costumava recompensar os serviços dos leais súditos. Embora

\footnotetext{
${ }^{39}$ AHU. Projeto Resgate. Serviço de Partes (avulsos). Cx. 2, D. 197. ANTT. Registro Geral de Mercês (Chancelaria) de D. Afonso VI. Livro 27, fls. 110-110v.

${ }^{40}$ BERREDO, B. P. de [1749]. Annaes historicos do Estado do Maranhão ..., tomo II, p. 426-427.

${ }^{41}$ AHU. Projeto Resgate. Pará (avulsos). Cx. 2, D. 114.
} 
governasse desde 1658, as inquirições sobre a conduta de Marçal Nunes da Costa incidiram basicamente sobre os acontecimentos de 1661, no final do seu triênio. Se esteve de algum modo implicado, as testemunhas inquiridas trataram de apagar - com que intenções não se sabe - os seus rastros, o que não era incomum nas devassas da atuação de oficiais régios, apesar da vigilância dos órgãos centrais no Reino e do esforço legislativo das monarquias ibéricas para regular a execução e o julgamento das residências no século XVII. ${ }^{42}$

Um sinal de discordância entre o que apurou a devassa e o que realmente se passou em 1661, envolvendo o sindicado, pode estar no registro feito por Berredo, no século XVIII, sobre a chegada de Marçal Nunes da Costa, em 1674, para assumir o cargo pela segunda vez. Afirmou que o capitão-mor servira 12 anos antes "com pouca aceitação dos seus moradores", sem expor claramente as razões desse descontentamento. ${ }^{43}$ Fato é que depois de voltar a Lisboa, Marçal Nunes da Costa continuou atuando nas guerras da Restauração, achando-se na recuperação da cidade de Évora aos castelhanos. Gozando a satisfação da Coroa pelos seus serviços no Pará, recebeu em 1668 nova carta patente para governar a sua fortaleza por mais três anos. ${ }^{44}$

Entre a nomeação e a posse transcorreram quase seis anos. Uma das causas desse lapso foi o verdadeiro périplo da travessia do Atlântico até o Maranhão. Não conseguindo romper a barra e entrar no porto de São Luís, o navio que conduzia o capitão-mor, filhos e criados, rumou para as Índias de Castela - onde Marçal Nunes da Costa perdeu todos os seus bens -, depois para os Países Baixos, Inglaterra e, finalmente, Portugal, jornada que teria consumido mais de 18 meses e deixado o capitão endividado. Para preparar nova viagem, precisou pedir uma ajuda de custo, deferida após consulta do Conselho Ultramarino, de 26 de setembro de $1672 .{ }^{45}$

A demora da partida de Lisboa também pode ser explicada pela espera do instrumento normativo que o guiaria, diferentemente de seus antecessores, no desempenho do seu ofício. $\mathrm{O}$ Regimento dos Capitães-mores do Pará, de 5 de junho de 1669, foi uma concessão do príncipe regente D. Pedro, expressa no título, em atenção a um pedido do capitão-mor no ano anterior:

\footnotetext{
${ }^{42}$ CAMARINHAS, N. As residências dos cargos de justiça letrada. In: STUMPF, R; CHATURVEDULA, N. (Orgs.). Cargos e ofícios nas monarquias ibéricas: provimento, controlo e venalidade (séculos XVII e XVIII). Lisboa: CHAM, 2012, p. 161-172. SANTOS PÉREZ, J. M. Visita, residência, venalidade. As "práticas castelhanas" no Brasil de Filipe III. In: MEGIANI, A. P. T.; SILVA, K. V.; SANTOS PÉREZ, J. M. (Eds.) O Brasil na monarquia hispânica (1580-1668): novas interpretações. São Paulo: Humanitas, 2016, p. 26-28.

${ }^{43}$ BERREDO, B. P. de [1749], 1849, tomo II, p. 544.

${ }^{44}$ ANTT. Registro Geral de Mercês (Chancelaria) de D. Afonso VI. Livro 11, fls. 41-42v.

${ }^{45}$ AHU. Consultas de Partes. Cód. 47, fls. 210-210v.
} 
Diz Marçal Nunes da Costa que Vossa Alteza lhe fez mercê de capitão-mor da capitania do Pará e porque está para se embarcar e se lhe não tem mandado passar seu Regimento como as mais capitanias do Estado do Brasil como a Paraíba que é sujeita [a]o governador da Bahia e tem Regimento[,] Pernambuco que também é capitania e[?] Rio de Janeiro que todas são sujeitas ao governador da Bahia e tem seu Regimento. ${ }^{46}$

Lembrou no requerimento a divisão do Estado do Maranhão e Grão-Pará (1652-1654), com a entrega de um Regimento a Inácio do Rego Barreto e, posteriormente, a separação do Rio de Janeiro do Governo-geral na Bahia, com a Repartição do Sul (1658-1662), confiada a Salvador Correia de Sá e Benevides, coincidentemente no período em que Marçal Nunes da Costa capitaneava em Belém pela primeira vez. Pela reivindicação, pretendia ter sua jurisdição delimitada, a fim de "acertar no serviço de Vossa Alteza, e saber as ordens que há de guardar e porque todos os capitães-mores que são feitos por Vossa Alteza são presos e mortos na prisão por causa de os governadores daquele Estado quererem tudo", pois, dessa prática nasciam os conflitos entre as duas hierarquias e as desordens na administração do Pará. ${ }^{47}$

\section{O REGIMENTO DE 1669}

Em 1623, Manuel de Sousa de Eça, nomeado “capitão-mor do presídio da conquista do Grão-Pará", requereu a Filipe III um "regimento particular para assim melhor acertar nas obrigações de seu cargo". Justificou o pedido pela distância entre Belém e São Luís, onde residia o governador e capitão-general do Estado do Maranhão, que por desconhecimento “daquelas partes não poderá resolver algumas matérias importantes ao serviço de Vossa Majestade e aumento da conquista, com a brevidade que às vezes convém". ${ }^{48}$ Diferentemente do Regimento dado, em 1615, a Francisco Caldeira de Castelo Branco, o de Manuel de Sousa de Eça seria o primeiro dos capitães-mores da capitania do Pará na condição de subalterna à principal do Maranhão.

\footnotetext{
${ }^{46}$ AHU. Projeto Resgate. Pará (avulsos). Cx. 2, D. 141.

${ }^{47}$ AHU. Projeto Resgate. Pará (avulsos). Cx. 2, D. 141.

${ }^{48}$ AHU. Projeto Resgate. Pará (avulsos). Cx. 1, D. 23.
} 
Essa subordinação, no entanto, só se efetivaria cinco anos depois, quando Francisco Coelho de Carvalho tomou posse como governador e capitão-general do Estado, em São Luís, e Manuel de Sousa de Eça, em Belém. ${ }^{49}$ Ao que parece, o capitão-mor não foi atendido, pois uma consulta do Conselho Ultramarino "sobre ser conveniente que os capitães da capitania do Pará, e do Maranhão, quando não houver governador, tenham regimento para saberem a jurisdição de que hão de usar”, de agosto de 1650, acusou a inexistência no Conselho Ultramarino e na Secretaria de Estado de "memória [...] de Regimento algum que se desse para o governo do Maranhão e capitania do Pará". 50

A consulta originou-se de uma carta do ouvidor do Maranhão denunciando as faltas e excessos cometidos pelos capitães-mores do Pará, "tão soberanos no cargo, que obram de potência grandes insolências contra os moradores, e muitas vezes sem jurisdição". Por essa razão, era de parecer que o rei lhes passasse Regimento, "e assim aos capitães da capitania do Maranhão, quando nela não estiver governador, para que usem dele, e não atendam ao que lhes não toca, porque parece que sua jurisdição se não resigne que para os atos militares, feitos na guerra, ou na paz, e eles se intrometem em tudo". ${ }^{11}$ Além da falta de um instrumento normativo que estabelecesse e delimitasse a jurisdição dos capitães-mores das duas capitanias, a carta e a consulta se referiam aos deslocamentos dos governadores e capitães-generais dentro dos limites da sua jurisdição. ${ }^{52}$ Quando estivessem ausentes da cabeça do Estado, seu lugar-tenente na capitania deveria se guiar por um regimento que, no entanto, restringia suas atribuições ao governo militar ou das armas, o mesmo se aplicando aos capitães-mores em Belém.

Dois anos depois, abolida a subordinação do Pará ao Maranhão (1652-1654), seus respectivos capitães-mores requereram os próprios Regimentos. ${ }^{53}$ Não há muitas informações sobre eles, mas certamente existiram. A carta patente de Baltazar de Sousa Pereira, por exemplo, o instruía a governar o Maranhão "na forma do regimento" que recebera. ${ }^{54} \mathrm{Na}$ capitania vizinha, a notícia da morte e da sucessão de Inácio do Rego Barreto, em 1654, trouxe à tona o capítulo 23 do seu Regimento, que versava sobre a aplicação da pena de degredo. ${ }^{55}$

\footnotetext{
${ }^{49}$ BERREDO, B. P. de [1749], 1849, tomo I, p. 236-241.

${ }^{50}$ AHU. Consultas Mistas. Cód. 14, fl. 249.

51 AHU. Consultas Mistas. Cód. 14, fl. 249.

52 SANTOS, F. V. dos. Entre São Luís e Belém: um estudo da dinâmica de governo no Estado do Maranhão e Grão-Pará (1673-1751). In: BORGES, E. J. S.; FLEXOR, M. H. O.; SEVERS, S. M. de S. S. (Org.). Poderes, identidades e sociedade na América portuguesa (séculos XVI-XVIII). São Paulo: Alameda, 2017, p. 163-188.

53 AHU. Projeto Resgate. Maranhão (avulsos). Cx. 3, D. 303.

${ }^{54}$ ANTT. Chancelaria de D. João IV. Livro 22, fl. 175.

55 AHU. Projeto Resgate. Pará (avulsos). Cx. 2, D. 90.
} 
Oito anos depois, uma consulta do Conselho Ultramarino mencionou o capítulo 17 para atestar o cuidado da Coroa em instruir governadores e capitães-mores sobre as vantagens da exploração do cravo e de outras drogas. ${ }^{56}$

Mesmo sem o conhecimento na íntegra do Regimento de Inácio do Rego Barreto, podese afirmar que as disposições do capítulo 23 se desdobraram nos capítulos 10 e 11, enquanto as do capítulo 17 foram reproduzidas no capítulo 24 do Regimento de 5 de junho de 1669, passado a Marçal Nunes da Costa. No primeiro caso, as instruções inovavam no tocante à jurisdição dos capitães-mores para a condenação ao degredo e, no segundo, a Coroa reiterava a necessidade de esforços "para que se continue a cultura do cravo, e anil, e cacau, e as mais drogas que nesse sertão houver". ${ }^{57}$ Portanto, o Regimento de Inácio do Rego Barreto (1652?) constituiu a memória de um conjunto de normas regimentais e serviu de modelo - não se sabe em que medida - para o Regimento de Marçal Nunes da Costa (1669), tido como o primeiro dado aos capitães-mores do Pará ${ }^{58}$, após a reunificação do Estado do Maranhão, em 1655. Além disso, refletia e ordenava questões relativas à colonização e à administração local, relacionadas à conjuntura da segunda metade do século XVII.

No quadro geral do Império português pós-Restauração, as últimas décadas dos Seiscentos foram marcadas por esforços diplomáticos para a manutenção das posições territoriais e comerciais lusas no Estado da Índia, frente à concorrência holandesa. Porém, ainda que tenha obtido algum resultado satisfatório, foi para o Atlântico que a monarquia de Bragança se voltou com mais afinco - expulsos os holandeses, em 1654, urgia recuperar as dinâmicas econômicas e reorganizar política e administrativamente o território. ${ }^{59}$ Sobre este segundo aspecto, em particular, verificou-se "a crescente importância política do Estado do Brasil, que passou por uma fase de ampliação e refinamento das jurisdições e poderes do governo-geral e dos governos de capitania, através da emissão de vários regimentos", como o dos capitães-

\footnotetext{
${ }^{56}$ AHU. Projeto Resgate. Maranhão (avulsos). Cx. 4, D. 461. Agradeço a Rafael Chambouleyron por gentilmente me indicar esta fonte. ${ }^{57}$ Arquivo da Universidade de Coimbra [AUC]. VI-III-1-1-30. Col. Condes dos Arcos (Pará). Liv. Regimentos do Estado de Maranhão e Pará. 1688-1764 s/n). Outro manuscrito do Regimento dos capitães-mores do Pará também pode ser encontrado no AHU. Cód. 169, fls. 49-53v.

${ }^{58}$ MARQUES, C. A. Diccionario histórico-geographico da provincia do Maranhão. São Luiz: Typographia do Frias, 1870, p. 223.

${ }^{59}$ RODRIGUES, J. D. Em busca da consolidação (c.1650-c.1700). In: COSTA, J. P. O.; RODRIGUES, J. D.; OLIVEIRA, P. A. (Coord.).

História da expansão e do império português. Lisboa: A Esfera dos Livros, 2014, p. 210-226.
} 
mores do Estado do Brasil (1663), dos governadores de Pernambuco (1670) e do governadorgeral Roque da Costa Barreto (1677). ${ }^{60}$

O Regimento de 1669 deve, portanto, ser incluído nesse movimento mais amplo de reordenamento das hierarquias governativas na América portuguesa, resguardadas as especificidades das suas disposições. Àquela altura, viviam-se no Estado do Maranhão os anos subsequentes a primeira expulsão dos jesuítas (1661), após uma revolta que teve entre suas causas a Lei de 9 de abril de 1655, que impôs restrições e novas regras para a escravidão indígena, apontadas pelos moradores como responsáveis por sua ruína. ${ }^{61}$ A legislação fortaleceu a atuação dos religiosos - uma das razões para a guerra justa e o legítimo cativeiro eram as resistências dos índios ao trabalho de evangelização -, e coibiu a iniciativa dos governadores na deflagração da guerra ofensiva. ${ }^{62}$ Pelo capítulo 6 do Regimento de 1669 , os capitães-mores do Pará deviam favorecer e não impor obstáculos à ação dos missionários, em nome da expansão da fé católica e, por conseguinte, da "conservação das conquistas". ${ }^{63}$

Com a diminuição dos rendimentos do comércio de especiarias no Oriente e a "atlantização" do Império, a Coroa portuguesa voltou sua atenção para a exploração das riquezas naturais encontradas nos sertões da capitania do Pará, as "drogas do sertão", atividade que se expandiria posteriormente ao Regimento. Assim, foram introduzidas no Estado do Maranhão novas leis sobre a liberdade dos índios (1680, 1686 e 1688) e uma companhia de comércio (1682) para promover a circulação das riquezas locais e o fornecimento de africanos escravizados. ${ }^{64}$ Sobre a extração dos gêneros da floresta, como foi dito, o capítulo 24 instruía o capitão-mor a dar continuidade à atividade, mantendo o governador informado de tudo. ${ }^{65}$

O conjunto de instruções guardava relação com o chamado Regimento dos capitãesmores (1570), quanto à função central do governante do Pará - tal como os capitães-mores das vilas e cidades portuguesas - de conhecer toda a gente de armas da capitania, passando mostras

\footnotetext{
${ }^{60}$ ARAÚJO, H. A. F. F. A construção da governabilidade no Estado do Brasil: perfil social, dinâmicas políticas e redes governativas do governo-geral (1642-1682). Tese (Doutorado em História), Programa de Pós-graduação em História Social, Universidade Federal do Rio de Janeiro, 2018, p. 82-83.

${ }^{61}$ CHAMBOULEYRON, R.; NEVES NETO, R. M. das. Os jesuítas e o "aumento e conservação" do Estado do Maranhão e Pará (século XVII). Clio - Série Revista de Pesquisa Histórica - N. 27-1, 2009, p. 76-104.

${ }^{62}$ FUNDAÇÃO BIBLIOTECA NACIONAL. Anais da Biblioteca Nacional [FBN/ABN]. Rio de Janeiro, 1948, vol. 66, p. 25-28.

${ }^{63}$ AUC. VI-III-1-1-30. Col. Condes dos Arcos (Pará). Liv. Regimentos do Estado de Maranhão e Pará. 1688-1764, s/n.

${ }^{64}$ CHAMBOUlEYRON, R. "As várias utilidades do Maranhão". Reflexões sobre o desenvolvimento da Amazônia no século XVII. In: NEVES, F. A. de F.; LIMA, M. R. P. (Org.). Faces da história da Amazônia. Belém: Paka-Tatu, 2006, p. 155-173. CHAMBOULEYRON, R. Povoamento, ocupação e agricultura na Amazônia colonial (1640-1706). Belém: Ed. Açaí; PPGH/UFPA; Centro de Memória da Amazônia (UFPA), 2010, p. 153-169. ARENZ, K. H.; MATOS, F. L. A. de. "Informação do Estado do Maranhão": uma relação sobre a Amazônia portuguesa no fim do século XVII. Revista do Instituto Histórico e Geográfico Brasileiro, Rio de Janeiro, vol. 463, 2014, p. 349-351.

${ }_{65}$ AUC. VI-III-1-1-30. Col. Condes dos Arcos (Pará). Liv. Regimentos do Estado de Maranhão e Pará. 1688-1764, s/n.
} 
duas vezes por ano, e de averiguar a capacidade de usá-las, "para que assim se consiga o benefício dito dos terem armas e saberem usar delas na ocasião" (capítulo 3). ${ }^{66}$ Ou seja, o propósito era o treinamento periódico dos homens capazes de pegar em armas (e que as possuíssem), e não simplesmente recrutá-los, como se diz do Regimento de $1570 .{ }^{67}$

A Marçal Nunes da Costa e seus sucessores foram concedidos poderes para prover interinamente postos de Guerra, Fazenda e Justiça, devendo reportar tais nomeações ao governador em São Luís (capítulo 5). Isso lhes dava prerrogativas de governo, entendido como o ato de administrar e de exercer jurisdição delegada pelo rei, por meio de regimentos e instruções ${ }^{68}$, não somente no campo militar, mas em outras esferas. Porém, se o Regimento de 1669 permitia aos capitães-mores do Pará fazer provimentos, colocava-os na tênue fronteira entre o pleno exercício da sua jurisdição e os conflitos com outros oficiais régios. Os capitãesmores estavam resguardados de interferências em sua jurisdição, mas também não podiam ingerir nos assuntos da Fazenda e da Justiça, e nos da Câmara de Belém. Cabia-lhes, no entanto, fiscalizar a arrematação e a cobrança dos dízimos, advertir provedores e ouvidores por faltas cometidas e reportar as reincidências ao governador (capítulos 7 e 8), o que abria caminho para contendas. Ao menos em tese era dessa forma que os reis visavam garantir, por meio da delegação de poderes (regalia) aos seus representantes na governação ultramarina - para prover postos, por exemplo -, o justo exercício das funções do governo (iurisdictio) e o seu equilíbrio. ${ }^{69}$

A permanência cada vez mais longa dos governadores e capitães-generais em Belém restringiu a aplicação do Regimento de 1669 desde o princípio do segundo governo de Marçal Nunes da Costa, em 1674, como afirmou Berredo:

[...] levava regimento, que lhe declarava a jurisdição do seu ministério; mas sendo o primeiro que se passou aos capitães-mores, teve pouco exercício [...] porque só podendo praticá-lo na ausência dos governadores, que faziam até aquele tempo a

\footnotetext{
${ }^{66}$ AUC. VI-III-1-1-30. Col. Condes dos Arcos (Pará). Liv. Regimentos do Estado de Maranhão e Pará. 1688-1764, s/n.

${ }^{67}$ COSTA, F. D. Insubmissão. Aversão ao serviço militar no Portugal do século XVIII. Lisboa: ICS, 2010, p. $146-151$.

${ }^{68}$ BLUTEAU, 1713, vol. 4, p. 103-104; 1720, vol. 7, p. 199-200.

${ }^{69}$ CARDIM, P. "Administração" e "governo": uma reflexão sobre o vocabulário do Antigo Regime. In: BICALHO, M. F.; FERLINI, V. L. A. (Org.). Modos de governar: ideias e práticas políticas no império português (séculos XVI a XIX). São Paulo: Alameda, 2005, p. 45-68. Para diferentes acepções dos conceitos de jurisdição e regalia, ver HESPANHA, A. M. Como os juristas viam o mundo, 1550-1750. Direitos, estados, pessoas, coisas, contratos, ações e crimes. Lisboa: Create Space Independent Publishing Platform, 2015, p. 33-49 e p. 181-186.
} 
sua residência na cidade de São Luís do Maranhão, a tinha mudado Pedro César [de Meneses] para aquela de Belém do Pará. ${ }^{70}$

A normatização das competências e da jurisdição dos capitães-mores do Pará era algo desconhecido no Estado do Maranhão havia quase vinte anos, desde que o Regimento de Inácio do Rego Barreto perdera o efeito, em 1655. A novidade parece ter suscitado dúvidas no governador - instalado em Belém um ano antes da posse de Marçal Nunes da Costa - o que explicaria o fato de ter escrito a Lisboa a respeito dos capítulos 5, 13, 14 e 26 do Regimento trazido por seu subordinado. Seus argumentos são desconhecidos porque a correspondência não foi localizada, apenas a resposta, na forma da carta régia de 3 de abril de $1675^{71}$, mas a julgar pelo teor das instruções citadas, calcula-se que Pedro César de Meneses pressentiu problemas decorrentes da sobreposição dos seus poderes aos do seu subalterno, agora munido de um instrumento que ordenava suas funções e jurisdição.

O capítulo 5 discorria sobre o provimento de ofícios. O capítulo 13 conferia ao capitãomor autoridade para despachar os navios aportados em Belém quando já estivessem carregados, mesmo que o governador ordenasse o contrário, enquanto o seguinte determinava o registro e o pagamento de direitos sobre índios resgatados e drogas do sertão na Alfândega do Pará, e não na Fortaleza do Gurupá. Aparentemente destoante dos demais, o capítulo 26 versava sobre as deferências entre o capitão-mor e o governador quando em visita ao Pará. Os questionamentos de Pedro César de Meneses talvez expressassem a sua reação, não propriamente ao ineditismo das formas de tratamento, mas à normatização da prerrogativa do capitão-mor de gozar do "respeito devido a vosso posto, pessoa e qualidade, procurando por todo o meio, que haja recíproca correspondência, entre um e outro, para que melhor se faça o meu Serviço"72, potencial argumento contra a subtração da jurisdição dos governantes do Pará.

Quanto ao que diziam os capítulos 5, 13 e 14, aparentemente estavam em jogo o controle e a execução de importantes medidas de ordem política, econômica e administrativa. Qual dos níveis hierárquicos sobrepostos no Pará caberia a precedência na escolha dos ocupantes dos cargos da Justiça e da Fazenda? Quais os interessados no pronto despacho das embarcações

\footnotetext{
${ }^{70}$ BERREDO, [1749], 1849, tomo II, p. 544.

${ }^{71}$ AHU. Cód. 268, fl. 9v.

${ }^{72}$ AUC. VI-III-1-1-30. Col. Condes dos Arcos (Pará). Liv. Regimentos do Estado de Maranhão e Pará. 1688-1764, s/n.
} 
para o Reino, quem os protegeria e por quê? Isso estaria relacionado à participação eventual do governador no negócio das drogas do sertão e/ou dos resgates?

Responder a estas e outras questões demandaria uma investigação à parte. Por ora, importa ressaltar que a chegada de Marçal Nunes da Costa com seu Regimento deflagrou conflitos. D. Pedro ordenou a Pedro César e a seus sucessores: "tenham entendido o que devem obrar, sem alterarem o dito Regimento". ${ }^{73}$ No entanto, em uma demonstração de como ordens e instrumentos normativos do Reino podiam ser recebidos e processados de outro modo nos espaços coloniais, as palavras do príncipe regente sucumbiram às dinâmicas políticas e administrativas no Estado do Maranhão.

\section{A IRA DO CAPITÃO-MOR OU O GOVERNO DO PARÁ NO SÉCULO XVII}

A pouca efetividade do Regimento dos capitães-mores do Pará e outras situações surgidas no cotidiano da governação deram ensejo a conflitos de jurisdição entre diferentes agentes da administração, que Marçal Nunes da Costa tratou com certo tom, ao mesmo tempo, irascível e jocoso. No princípio do seu segundo governo no Pará (1674-1685), em uma petição ao rei $^{74}$, contestou o capítulo 31 do Regimento dos governadores e capitães-generais do Estado do Maranhão (1655), pelo qual eles poderiam suspender os capitães-mores do Pará, nos casos mencionados no tópico anterior. Sendo assim, o governador estaria autorizado a prover em lugar do capitão-mor suspenso "pessoas de confiança", reportando a decisão ao rei pelo Conselho Ultramarino.

De acordo com a petição, subida à consulta do órgão, Marçal Nunes da Costa alegava que apesar de estar subordinado ao governador do Estado do Maranhão, segundo o capítulo 4 do seu Regimento, e do que previa o capítulo 31 do Regimento dos governadores e capitãesgenerais, havia jurado preito e menagem ao rei, por isso, só o monarca poderia suspendê-lo. Pedia, portanto, que se alterasse o capítulo 31 do Regimento dos seus superiores, pois estes, em conluio com ouvidores - sobre os quais os capitães-mores não tinham jurisdição, consoante o capítulo 8 do Regimento de 1669 -,

\footnotetext{
${ }^{73}$ AUC. VI-III-1-1-30. Col. Condes dos Arcos (Pará). Liv. Regimentos do Estado de Maranhão e Pará. 1688-1764, s/n. ${ }^{74}$ AHU. Projeto Resgate. Pará (avulsos). Cx. 2, D. 149.
} 
[...] formarão culpas para proverem o dito posto por suas conveniências e em sujeitos de sua facção; e enquanto se averigua a verdade, acabam os governadores o seu tempo, e os ditos capitães-mores padecem, e ficam destruídos, e desacreditados, como sucedeu a Francisco de Seixas Pinto, que morreu na prisão, Antônio Pinto da Gaia, Manuel de Sá, Jácome Raimundo de Noronha, Francisco [sic] de Lucena, e outros. ${ }^{75}$

O requerimento de Marçal Nunes da Costa foi considerado improcedente pelos conselheiros, "pois não tem o Regimento culpa, e o governador que o não guardar sim, que não o observando se deve proceder contra ele". Ou, segundo outro conselheiro,

[...] que se não deve emendar o capítulo do Regimento, porque ficando os capitãesmores do Pará absolutos de serem pelos governadores do Maranhão emprazados e dispostos [sic] de seu cargo, pelas exorbitâncias que executam, de que há muitas queixas, ficarão absolutos para procederem sem temor, nem castigo. ${ }^{76}$

Em outro momento, no final do seu governo no Pará e nos últimos meses de Francisco de Sá de Meneses à frente do Estado do Maranhão, o capitão-mor escreveu ao rei queixandose do que considerava uma dupla usurpação de sua jurisdição: "Os governadores como assistentes nesta capitania, todo o tempo de seu governo, recebem as propinas dos dízimos de V.M., que estas me pertencem assim, como capitão-mor dela, que não basta usurpar-me a jurisdição, senão ainda as propinas e prós que a mim direitamente me tocam". ${ }^{77}$

Depois de mais de 50 anos de serviços, com boa residência do primeiro governo, velho e "dissipado de jurisdição com a assistência dos governadores nela", utilizou-se da retórica típica dos requerimentos de mercês para pedir um acrescentamento ao posto, talvez um aumento de soldo, ou uma comissão em outro lugar. ${ }^{78}$ Isto pode ter sido a razão de acusar, além da perda de jurisdição, também a das propinas dos dízimos do Pará, embolsados pelos governadores. Reflexo da sua fixação regular em Belém a partir de Pedro César de Meneses (1671-1678) e, principalmente, de Inácio Coelho da Silva (1678-1682), que recebeu ordens de Lisboa para

\footnotetext{
75 AHU. Projeto Resgate. Pará (avulsos). Cx. 2, D. 149. AHU. Consultas de Partes. Cód. 47, fls. 275-275v.

${ }^{76}$ AHU. Projeto Resgate. Pará (avulsos). Cx. 2, D. 149.

77 AHU. Projeto Resgate. Pará (avulsos). Cx. 3, D. 237.

${ }^{78}$ AHU. Projeto Resgate. Pará (avulsos). Cx. 3, D. 238.
} 
residir naquela cidade, a fim de explorar as potencialidades do cacau e da baunilha, reparar as fortificações e guarnecer a fronteira do Cabo do Norte com a Guiana Francesa. ${ }^{79}$

Já no governo de Francisco de Sá de Meneses (1682-1685), a ameaça de uma invasão vinda de Caiena - que se prolongaria pelas décadas seguintes - foi o mote para o capitão-mor desferir mais um ataque. Escreveu ao rei denunciando os problemas crônicos de falta de munição e do mau estado do aparelho defensivo da capitania, de modo irônico, como se na prática não respondesse mais por ela: "Pela homenagem que dei nas reais mãos de Vossa Majestade me obriga a dar parte desta capitania, e fortaleza dela, se bem a deve dar o governador Francisco de Sá de Meneses, que a governa”. Na mesma carta, aproveitou para fustigar seus superiores, pedindo a permissão do rei para consertar a Fortaleza do Pará - uma atribuição inerente ao seu posto -, pela qual havia dado preito e menagem, "pois os governadores não olham para ela porque só põem os olhos em os interesses do cravo, causa de os fazer assistir nesta capitania, e não na cabeça do Estado onde é sua obrigação". ${ }^{80}$

As denúncias de Marçal Nunes da Costa chamam atenção para ao menos dois aspectos: os ritos de nomeação e de transmissão de poderes aos oficiais régios, por meio de suas cartas patentes e regimentos, e a forma particular como os agentes liam e interpretavam esses documentos. Sobre o primeiro aspecto, destaca-se o preito e menagem. Nessa cerimônia, de origem medieval, aqueles designados para exercer algum poder delegado pelo rei (regalia), no Reino ou nos domínios ultramarinos, prestavam o juramento de fidelidade ao monarca. Os governantes ultramarinos (vice-reis, governadores-gerais ou governadores de capitania) faziam-no antes de partir, como previam suas patentes. Desse modo, o ritual "concedia consistência e legitimidade às práticas delegativas de poder, como era a nomeação de alguns governantes das conquistas ultramarinas". ${ }^{81}$

Na carta que o capitão-mor dirigiu a D. Pedro II, em 1685, há também outro elemento constante nas cartas patentes dos governantes ultramarinos, logo após a enumeração dos serviços e das experiências que justificavam a concessão da mercê do posto, como na carta patente de Marçal Nunes da Costa: "Hei por bem fazer-lhe mercê da capitania mor do Pará, para que a sirva por tempo de três anos e o mais enquanto lhe não mandar sucessor com a qual

\footnotetext{
${ }^{79}$ AHU. Projeto Resgate. Pará (avulsos). Cx. 5, D. 621.

${ }^{80}$ AHU. Projeto Resgate. Pará (avulsos). Cx. 3, D. 239.

${ }^{81}$ COSENTINO, F. C. Governadores Gerais do Estado do Brasil (séculos XVI-XVII): ofício, regimentos, governação e trajetórias. São Paulo: Annablume/Fapemig, 2009, p. 85-101.
} 
haverá o soldo que lhe tocar e todos os prós e percalços que direitamente lhe pertencerem". ${ }^{82}$ Dessa forma, o capitão-mor governaria não só pelos três anos comumente atribuídos aos administradores coloniais, mas também enquanto o rei assim o desejasse, e com todos os bônus (prós) que lhes competiam, como o recebimento das propinas pela arrematação dos dízimos do Pará, e os ônus (percalços), os encargos inerentes ao ofício, cujo desempenho poderia acarretar prêmio ou castigo.

Esses elementos realçados no discurso peticionário de Marçal Nunes da Costa ilustram o modo particular como os oficiais régios liam e interpretavam suas cartas patentes de nomeação e os instrumentos ordenadores da administração - os regimentos. Assim, é possível entender a posição dos conselheiros do Conselho Ultramarino. O problema em si não estava no Regimento de 1655, cujo capítulo 31 Marçal Nunes da Costa pretendia que fosse alterado, mas no seu eventual descumprimento pelos governadores e capitães-generais. O mesmo raciocínio se aplicava ao Regimento de 1669, especialmente, no que respeitava à subordinação do capitãomor do Pará ao governador e capitão-general do Estado do Maranhão.

Como o próprio Marçal Nunes da Costa deu a conhecer em suas queixas, ele não foi o primeiro capitão-mor a sofrer e criticar abertamente a intromissão de um governador em sua jurisdição ou seus excessos. Neste caso se encaixava Sebastião de Lucena de Azevedo (16461648). Cavaleiro professo na Ordem de Cristo, havia servido à Coroa nas guerras contra os holandeses em Pernambuco, no comando da caravela São Francisco Xavier, levando munições e soldados para socorrer o governador da capitania, Matias de Albuquerque. ${ }^{83}$ Mas, nunca havia pisado no Pará ou no Maranhão, como um seu antecessor, o já citado Manuel Madeira, ao contrário de outros indivíduos envolvidos na conquista daquelas terras e/ou nelas enraizados, por exemplo, Aires de Sousa Chichorro e Bento Maciel Parente. Lucena foi também o primeiro capitão-mor do Pará escolhido pelo escrutínio do Conselho Ultramarino ${ }^{84}$, algo que pode ter sido mal-recebido em Belém, acostumada a constantes trocas de capitão-mor por "homens bons" do lugar, ou que transitavam também pelo Maranhão, e gozavam a confiança dos governadores e/ou da principal instância de representação do poder local.

\footnotetext{
${ }^{82}$ ANTT. Registro Geral de Mercês (Chancelaria) de D. Afonso VI. Livro 11, fls. 41-42v.

${ }^{83}$ ANTT. Mesa da Consciência e Ordens. Habilitações da Ordem de Cristo. Letra S, maço 6, no 45. AHU. Projeto Resgate. Brasil Geral (avulsos). Cx. 1, D. 17.

${ }^{84}$ AHU. Projeto Resgate. Pará (avulsos). Cx. 1, D. 55.
} 
Foi justamente a Câmara de Belém quem deu o voto de desconfiança a Sebastião de Lucena de Azevedo, malquistando-se com o capitão por divergir da forma como ele pretendia conduzir a defesa da cidade, em caso de uma nova investida holandesa. Por volta de junho de 1647, a Câmara argumentou que Lucena deveria lançar mão dos poucos índios e armas disponíveis para defender a praça e pediu que cessassem as prisões de moradores: "Requeiro a Vossa Mercê Senhor capitão-mor da parte de Deus e d' El Rei Nosso Senhor em nome deste Povo que Vossa Mercê não cative os poucos moradores que há nesta capitania nem ao capitão da ordenança com a companhia nesta fortaleza". O capitão-mor contra-argumentou, dizendo: “Eu não trato de posto, nomeá-los sem ver o inimigo, nem saber donde pode acometer-nos; trato a segurança desta Fortaleza de Sua Majestade que Deus Guarde que é o verdadeiro posto que havemos de guardar". ${ }^{85}$

Sebastião de Lucena defendia que sua obrigação era defender apenas a Fortaleza do Pará, na paz e na guerra, conforme o preito e menagem que havia jurado e constava em sua carta patente. Tanto que, ainda em 1647, meses depois do requerimento da Câmara, subiu ao Conselho Ultramarino uma consulta sobre pedido do capitão de pólvora e de munições para a Fortaleza, que além do péssimo estado de conservação, contava com pouca artilharia e não havia ninguém capaz de repará-la. ${ }^{86}$ No mesmo ano, foi suspenso pelo governador Francisco Coelho de Carvalho, o Sardo, que acusou o capitão-mor de negligenciar "a obrigação que tinha de guardar a ordem de V.M. e o que ele governador lhe ordenava por seu regimento como seu capitão-general", pois "levado de seus interesses, mandou aprestar canoas com soldados, e o gentio que havia, a que mandou com um capitão ao sertão, a cativar os índios. ${ }^{87}$ De acordo com Alexandre Pelegrino, Sebastião de Lucena estava "envolvido até o último fio de cabelo com a exploração do trabalho indígena e o tráfico de escravos". ${ }^{88}$ Porém, em 6 de setembro de 1649 , o principal dos Tabajaras Antônio da Costa Marapirão e outros principais escreveram a D. João IV para se queixar dos governadores e dos capitães-mores do Pará, com exceção de Lucena, que retirou os filhos dos índios da escravidão em casa de moradores, fez com que seus serviços fossem pagos e deu-lhes tempo para fazerem suas próprias roças. Ocorre que, diferentemente

\footnotetext{
${ }^{85}$ AHU. Projeto Resgate. Pará (avulsos). Cx. 1, D. 66 e D. 68.

${ }^{86}$ AHU. Projeto Resgate. Pará (avulsos). Cx. 1, D. 71.

87 AHU. Projeto Resgate. Maranhão (avulsos). Cx. 2, D. 225. AHU. Cód. 1275, fl. 1.

${ }^{88}$ PELEGRINO, A. de C. Donatários e poderes locais no Maranhão seiscentista (1621-1701). Dissertação de Mestrado. Niterói/RJ: Programa de Pós-graduação em História Social, Universidade Federal Fluminense, 2015, p. 84-85.
} 
de outros capitães-mores, Lucena era prático na língua dos índios, daí terem clamado ao rei que lhes mandasse "governador com quem nos entendamos e nos entenda nossa língua" ${ }^{89}$

Um segundo e último exemplo das tentativas de contestar a ingerência dos governadores do Estado do Maranhão na jurisdição dos capitães-mores do Pará ocorreu no tempo de Francisco de Seixas Pinto (1662-1665). Sucedeu a Marçal Nunes da Costa em seu primeiro governo e chegou no momento nevrálgico em que os jesuítas estavam para ser restituídos às suas missões, após a concessão do perdão real aos moradores pela revolta de 1661. Esse foi, aliás, o pomo da discórdia entre o capitão-mor e o governador. Segundo Francisco de Seixas Pinto, Rui Vaz de Siqueira o emprazou, destituiu e mandou prender em casa "só por ser meu inimigo, por eu querer se publicasse a lei de Vossa Majestade”, que garantia aos padres da Companhia de Jesus o retorno à atividade missionária. No lugar do capitão deposto entrou Feliciano Correia, provido pelo governador, ferindo não apenas o capítulo 31 do seu regimento, mas o 34, que o proibia de criar postos e de aumentar soldos. Na interpretação de Seixas Pinto, tanto a nomeação de um interino, quanto a posse de seu sucessor, Antônio Pinto da Gaia, que recebeu "a praça da mão de Feliciano Correia que o governador deste Estado Rui Vaz de Siqueira havia criado em seu loco-tenente", eram irregulares. ${ }^{90}$

A usurpação da jurisdição fez com que Francisco de Seixas Pinto redigisse um conjunto de protestos $^{91}$ à Coroa, nos quais pormenorizou a sua trajetória, desde a escolha para governar o Pará até a destituição e prisão pelo governador. A crítica de Francisco de Seixas Pinto tinha relação direta com a presença de Rui Vaz de Siqueira em Belém - que viria a ser frequente com seus sucessores -, sobrepondo-se à sua investidura na capitania-mor da Fortaleza do Pará, conforme o preito e menagem jurado nas mãos do rei. Quando Antônio Pinto da Gaia foi impedido pelo governador de entregar a Seixas Pinto a carta de guia, documento que levantava o juramento de preito e menagem, desobrigando-o da capitania-mor do Pará e permitindo-lhe voltar para o Reino, sua prisão tornou-se ainda mais intolerável. Era como se não fosse reconhecido como capitão-mor em exercício - daí ter protestado contra a entrega do cargo a Antônio Pinto da Gaia por Feliciano Correia.

\footnotetext{
${ }^{89}$ AHU. Projeto Resgate. Pará (avulsos). Cx. 1, D. 71. Agradeço a Rafael Chambouleyron por gentilmente me indicar esta fonte. AHU. Consultas Mistas. Cód. 14, fls. 348v.

${ }^{90}$ AHU. Projeto Resgate. Pará (avulsos). Cx. 2, D. 127 e D. 131

91 AHU. Projeto Resgate. Pará (avulsos). Cx. 2, D. 131. Protesto ou protestação jurídica era uma "declaração pública, da qual se faz um ato, contra a opressão, violência, ou nulidade de alguma ação, sentença, etc., apelando para outro a seu tempo, e lugar”. BLUTEAU, 1720, vol. 6, p. 795-796.
} 
Francisco de Seixas Pinto não teve êxito em sua defesa e terminou seus dias preso. Antônio Pinto da Gaia também não pôde se gabar da sorte. Foi destituído da capitania do Pará por Antônio de Albuquerque Coelho de Carvalho, o velho, e rendido por Manuel Guedes Aranha, seguido por Paulo Martins Garro e Feliciano Correia, à altura, provedor da Santa Casa da Misericórdia de Belém..$^{92} \mathrm{O}$ motivo da destituição de Antônio Pinto da Gaia causou estranheza a Bernardo Pereira de Berredo, que sem dar maiores explicações sobre o ocorrido, fez o seguinte questionamento: "como se uma queixa particular bastasse a tão severa demonstração, principalmente quando para ela se expressavam os casos no mesmo Regimento dos governadores". ${ }^{93} \mathrm{O}$ desfecho da situação, no entanto, favoreceu o capitão-mor, restituído ao cargo após dois anos e meio para cumprir o triênio a que tinha direito por nomeação régia.

A suspensão arbitrária de capitães-mores do Pará - geralmente reinóis e providos por patente régia - e a sua substituição por homens estabelecidos na terra, foi um traço comum no Pará do século XVII. Quando o Conselho Ultramarino apreciou o requerimento de Marçal Nunes da Costa para que o capítulo 31 do Regimento dos governadores e capitão-generais fosse modificado, o procurador da Coroa se manifestou dizendo que "a experiência tinha mostrado em vários casos, suspenderem os governadores aos capitães-mores, com pretextos indecentes, para darem as capitanias a outros, de que tiram lucros notáveis". ${ }^{94}$ Mas nem eles estariam livres dos desmandos dos governadores, como deixa entrever uma carta de Manuel Guedes Aranha a D. Pedro, de 1668, quando substituiu Antônio Pinto da Gaia. Denunciou o abandono de Belém e a precariedade das suas defesas, devido ao fato de "as pessoas que vêm a governá-las tratarem somente com toda a ânsia de seus interesses", ao contrário dele, natural da terra e filho de um conquistador. A intenção era convencer o príncipe a provê-lo na capitania-mor do Pará, com jurisdição sobre todas as anexas (as capitanias donatárias), por seis anos, assim como Inácio do Rego Barreto, em 1652. Isto é, com independência do governo do Maranhão. Com isso, ficaria livre da ameaça de ser destituído por alguma desinteligência com o governador e, em troca, faria tudo para defender o território e a liberdade dos índios. ${ }^{95}$

Após o término do segundo governo de Marçal Nunes da Costa, em 1685, houve apenas uma suspensão de capitão-mor no Pará: Manuel de Madureira Lobo, destituído em 1723, pelo

\footnotetext{
92 AHU. Projeto Resgate. Pará (avulsos). Cx. 2, D. 133. BAENA, 1838, p. 122-124.

${ }^{93}$ BERREDO, [1749], 1849, tomo II, p. 527-528.

${ }^{94}$ AHU. Projeto Resgate. Pará (avulsos). Cx. 2, D. 149.

95 AHU. Projeto Resgate. Pará (avulsos). Cx. 2, D. 89 e D. 137.
} 
governador João da Maia da Gama (1722-1728), que nomeou José Velho de Azevedo, um reinol, e Pedro Mendes Tomás, cidadão de Belém. Ambos tinham negócios bem assentados no Pará e já haviam ocupado o posto de capitão-mor. ${ }^{96}$

\section{CONSIDERACÕES FINAIS}

Por abordar resultados parciais de pesquisa, não era de esperar que este artigo deixasse mais respostas do que indagações e lacunas sobre as práticas governativas no Pará seiscentista. Marçal Nunes da Costa foi escolhido como porta-voz de questões ligadas à dinâmica política e administrativa na capitania subalterna, justamente porque sua fala propiciou as condições para iniciar um debate sobre as relações entre as hierarquias governativas no Estado do Maranhão. Contudo, há muito mais elementos associados aos desentendimentos entre capitães-mores e governadores e capitães-generais.

Nesse sentido, analisar os termos das cartas patentes de nomeação e os regimentos desses administradores coloniais é um exercício historiográfico atual e relevante para a renovação dos estudos de história política e da administração colonial - o Regimento dos capitães-mores do Pará é certamente menos conhecido que o dos capitães-mores do Estado do Brasil (1663), assim como o Regimento dos governadores e capitães-generais do Estado do Maranhão (1655) não recebeu a mesma atenção dada, por exemplo, ao do governador-geral do Estado do Brasil, Roque da Costa Barreto (1677).

Mas, é preciso avançar na compreensão das dinâmicas resultantes da aplicação dos dispositivos regimentais e dos poderes delegados pelos soberanos portugueses aos seus agentes no ultramar, a fim de se perceber que muitos conflitos de jurisdição ou arbitrariedades vivenciados e cometidos por oficiais régios, nas mais diversas funções, não estavam relacionados apenas à aplicabilidade das suas instruções ou à exorbitância de autoridade, mas à forma como esses agentes interpretavam seus regimentos, patentes e demais leis da monarquia e se relacionavam com a realidade social, política, econômica e cultural com que se deparavam e com a qual interagiam nos territórios coloniais. Atenta às situações conflituosas gestadas nos seus domínios de além-mar, a Coroa procurava compor soluções, por intermédio de órgãos

${ }^{96}$ AHU. Cód. 209, fls. 17-17v. 
consultivos, como o Conselho Ultramarino, tal como no desfecho do caso de Sebastião de Lucena de Azevedo.

Marçal Nunes da Costa não estava propriamente errado. Militar experiente e sexagenário quando chegou a Belém pela segunda vez, queria que sua delegação e atribuições - a capitania-mor e o governo das armas do Pará - fossem respeitadas nos termos em que foram gravadas na patente de nomeação e no regimento que peticionou à Coroa. Não pretendia, portanto, renunciar à sua autoridade, mas teve que ceder aos imperativos da dinâmica administrativa que sobrepôs aos seus poderes de capitão-mor os do seu superior hierárquico, instalado em Belém. Não lhe restou alternativa a não ser denunciar o que julgava ilegítimo.

Por outro lado, não é possível afirmar que o capitão não participou ou se envolveu em negócios no Pará. Afinal, o que explicaria sua permanência no cargo de 1674 a 1685, passando por três governos sucessivos até o início do quarto, de Gomes Freire de Andrade? Sua capacidade de negociação com os governadores é difícil de aceitar. Afinidades com grupos de poder local podem ser cogitadas, mas o capitão-mor denunciou a Câmara de Belém por não repartir com ele índios resgatados nos sertões. ${ }^{97}$ A narrativa dos cronistas, por vezes confusa e incongruente, e a ausência de documentação (da Câmara de Belém, por exemplo) contribuem para deixar muitas questões em aberto.

Uma resposta possível está na itinerância do governo e dos governadores do Estado do Maranhão para a capitania do Pará, mais constante e duradoura justamente a partir do início da segunda passagem de Marçal Nunes da Costa por Belém. A presença dos superiores na cidade, transformada em cabeça do Estado, na prática relegou os seus capitães-mores a delegados dos governadores, e não do rei que os nomeava. Não havia por que serem emprazados e destituídos com a mesma frequência de quando seus superiores passavam mais tempo em São Luís, o que explicaria a estabilidade dos capitães-mores depois de 1685. Deve haver outras possibilidades de explicação para isso e para os estranhamentos entre governadores e capitães-mores. Estudos de caso talvez possam elucidar o que havia de recorrente e peculiar nos episódios de dissensão entre esses dois níveis hierárquicos da governação do Estado do Maranhão, que também envolviam outros atores, índios, moradores, missionários, a Câmara e demais oficiais régios.

\footnotetext{
${ }^{97}$ AHU. Consultas de Partes. Cód. 47, fls. 408v-409. FBN/ABN. Rio de Janeiro, 1948, vol. 66, p. 48.
} 


\section{REFERÊNCIAS}

Fontes

Manuscritos

ARQUIVO HISTÓRICO ULTRAMARINO (AHU) - Projeto Resgate (avulsos e códices). Brasil Geral: Cx. 1, D. 17. . Maranhão: Cx. 1, D. 94; Cx. 2, D. 225; Cx. 3, D. 265, D. 291 e D. 303; Cx. 4, D. 461. . Pará: Cx. 1, D. 23, D. 43, D. 55, D. 66, D. 68, D. 71 e D. 76; Cx. 2, D. 89, D. 90, D. 114, D. 127 , D. 131, D. 133, D. 137, D. 141 e D. 149; Cx. 3, D. 237, D. 238 e D. 239; Cx. 5, D. 621 Serviço de Partes: Cx. 2, D. 197.

_. Consultas Mistas: Cód. 14 e Cód. 15.

_ Consultas de Partes: Cód. 47.

__. Livro de registro de regimentos do Conselho Ultramarino, 1642-1807: Cód. 169.

. Ordens régias de 1648 até 1797, que se acham registradas nos livros de registro da Câmara do Pará: Cód. 1275.

. Registro de cartas régias para o governador e outras entidades da capitania do Maranhão (1673-1712): Cód. 268.

. Registro de consultas sobre diferentes assuntos referentes às capitanias do Maranhão e Pará (1722-1758): Cód. 209.

ARQUIVO NACIONAL DA TORRE DO TOMBO (ANTT). Chancelaria de Filipe III. Doações: Livro 18 e Livro 28.

_. Mesa da Consciência e Ordens. Habilitações da Ordem de Cristo. Letra S, maço 6, nº 45

_. Registro Geral de Mercês. D. João IV: Livro 4.

_. Registro Geral de Mercês (Chancelaria). D. Afonso VI: Livro 11 e Livro 27.

ARQUIVO DA UNIVERSIDADE DE COIMBRA (AUC). Col. Condes dos Arcos (Pará). Liv. Regimentos do Estado de Maranhão e Pará. 1688-1764. VI-III-1-1-30, s/n.

BIBLIOTECA NACIONAL DE PORTUGAL (BNP). Cópia do Regimento de alguns capítulos do Governador do Maranhão, que se passou a Francisco Coelho de Carvalho: Cód. 7627.

Impressos 
BAENA, A. L. M. Compêndio das eras da província do Pará. Belém: Typographia de Santos \& Santos Menor, 1838.

BAENA, A. L. M. [1833] Ensaio corográfico sobre a província do Pará. Brasília: Edições do Senado Federal, 2010.

BERREDO, B. P. de [1749]. Annaes historicos do Estado do Maranhão, em que se dá notícia do seu descobrimento, e tudo o mais que nelle tem succedido desde o anno em que foy descuberto até o de 1718. $2^{\mathrm{a}}$ ed. São Luiz: Typographia Maranhense, 1849, t. I e t. II.

BETTENDORFF, J. F. [1698] Crônica da missão dos padres da Companhia de Jesus no Estado do Maranhão. Brasília: Edições do Senado Federal, 2010.

BLUTEAU, R. Vocabulario portuguez \& latino. Coimbra: Collegio das Artes da Companhia de Jesu, 1712-1720, vols. 2, 3, 4, 6 e 7.

FUNDAÇÃO BIBLIOTECA NACIONAL. Anais da Biblioteca Nacional. Rio de Janeiro,1948, vol. 66.

HERIARTE, M. de [1662]. Descripção do Estado do Maranhão, Pará, Corupá e Rio das Amazonas. Vienna d'Áustria: Imprensa do filho de Carlos Gerold, 1874.

MARQUES, C. A. Diccionario histórico-geographico da provincia do Maranhão. São Luiz: Typographia do Frias, 1870.

\section{Obras Gerais}

AMARAL, J. R. do. Fundação de Belém do Pará: jornada de Francisco Caldeira de Castelo Branco, em 1615-1616. Brasília: Edições do Senado Federal, 2004.

ARAÚJO, H. A. F. F. A construção da governabilidade no Estado do Brasil: perfil social, dinâmicas políticas e redes governativas do governo-geral (1642-1682). Tese (Doutorado em História), Programa de Pós-graduação em História Social, Universidade Federal do Rio de Janeiro, 2018.

ARENZ, K. H.; MATOS, F. L. A. de. "Informação do Estado do Maranhão": uma relação sobre a Amazônia portuguesa no fim do século XVII. Revista do Instituto Histórico e Geográfico Brasileiro, Rio de Janeiro, vol. 463, 2014, p. 349-351.

BICALHO, M. F.; MONTEIRO, N. G. As instituições civis da monarquia portuguesa na Idade Moderna: centro e periferia do império. In: XAVIER, A. B.; PALOMO, F.; STUMPF, R. (Org.). Monarquias ibéricas em perspectiva comparada (sécs. XVI-XVIII): dinâmicas imperiais e circulação de modelos administrativos. Lisboa: ICS, 2018. 
CAMARINHAS, N. As residências dos cargos de justiça letrada. In: STUMPF, R; CHATURVEDULA, N. (Org.). Cargos e ofícios nas monarquias ibéricas: provimento, controlo e venalidade (séculos XVII e XVIII). Lisboa: CHAM, 2012, p. 161-172.

CARDIM, P. "Administração" e "governo": uma reflexão sobre o vocabulário do Antigo Regime. In: BICALHO, M. F.; FERLINI, V. L. A. (Org.). Modos de governar: ideias e práticas políticas no império português (séculos XVI a XIX). São Paulo: Alameda, 2005.

CARDOSO, A. C. Maranhão na monarquia hispânica: intercâmbios, guerra e navegação nas fronteiras das Índias de Castela (1580-1655). Tese (Doutorado), Facultad de Geografía e Historia, Departamento de Historia Medieval, Moderna, Contemporánea y de América, Universidad de Salamanca 2012.

CHAMBOULEYRON, R. Povoamento, ocupação e agricultura na Amazônia colonial (16401706). Belém: Ed. Açaí; PPGH/UFPA; Centro de Memória da Amazônia (UFPA), 2010.

CHAMBOULEYRON, R. "As várias utilidades do Maranhão". Reflexões sobre o desenvolvimento da Amazônia no século XVII. In: NEVES, F. A. de F.; LIMA, M. R. P. (Org.). Faces da história da Amazônia. Belém: Paka-Tatu, 2006.

CHAMBOULEYRON, R.; NEVES NETO, R. M. das. Os jesuítas e o "aumento e conservação" do Estado do Maranhão e Pará (século XVII). Clio - Série Revista de Pesquisa Histórica - N. 27-1, 2009, p. 76-104.

CORRÊA, H. M. M. “Para aumento da conquista e bom governo dos moradores": o papel da Câmara de São Luís na conquista, defesa e organização do território do Maranhão (1615-1668). Tese (Doutorado em História), Programa de Pós-graduação em História Social, Universidade Federal Fluminense, Niterói, 2011.

COSENTINO, F. C. Governadores Gerais do Estado do Brasil (séculos XVI-XVII): ofício, regimentos, governação e trajetórias. São Paulo: Annablume/Fapemig, 2009.

COSTA, F. D. Insubmissão. Aversão ao serviço militar no Portugal do século XVIII. Lisboa: ICS, 2010.

CURVELO, A. A. S. de C. O Senado da Câmara de Alagoas do Sul: governança e poder local no Sul de Pernambuco (1654-1751). Dissertação (Mestrado em História), Programa de Pósgraduação em História, Universidade Federal de Pernambuco, Recife, 2014.

CRUZ, E. História de Belém. Belém: Universidade Federal do Pará, 1973, vol. I.

HESPANHA, A. M. Como os juristas viam o mundo, 1550-1750. Direitos, estados, pessoas, coisas, contratos, ações e crimes. Lisboa: Create Space Independent Publishing Platform, 2015.

HESPANHA, A. M. As vésperas do Leviathan. Instituições e poder político, Portugal - séc. XVII. Coimbra: Livraria Almedina, 1994. 
MARQUES, G. Entre deux empires: le Maranhão dans 1'Union Ibérique (1614-1641). Nuevo Mundo Mundos Nuevos. Débats, 2010, p. 6. Disponível em: 〈http://journals.openedition.org/nuevomundo/59333〉. Acesso em: jan. 2021.

PELEGRINO, A. de C. Donatários e poderes locais no Maranhão seiscentista (1621-1701). Dissertação (Mestrado em História), Programa de Pós-graduação em História Social, Universidade Federal Fluminense, Niterói, 2015.

PEREIRA, C. A. L. A Capitania-mor do Mar da Índia (1502-1564). Dissertação (Mestrado), Faculdade de Ciências Sociais e Humanas, Universidade Nova de Lisboa, Lisboa, 2016.

ROCHA, R. A. A elite militar no Estado do Maranhão: poder, hierarquia e comunidades indígenas (século XVII). Tese (Doutorado em História), Programa de Pós-graduação em História Social, Universidade Federal Fluminense, Niterói, 2013.

RODRIGUES, J. D. Em busca da consolidação (c.1650-c.1700). In: COSTA, J. P. O.; RODRIGUES, J. D.; OLIVEIRA, P. A. (Coord.). História da expansão e do império português. Lisboa: A Esfera dos Livros, 2014, p. 205-234.

RODRIGUES, J. D. O poder municipal do Antigo Regime ao Liberalismo: da autonomia jurisdicional às Juntas Gerais. Actas do Congresso $1^{\circ}$ Centenário da Autonomia dos Açores. Ponta Delgada, 1995, vol. 1, p. 103-126.

SANTOS, F. V. dos. Entre São Luís e Belém: um estudo da dinâmica de governo no Estado do Maranhão e Grão-Pará (1673-1751). In: BORGES, E. J. S.; FLEXOR, M. H. O.; SEVERS, S. M. de S. S. (Org.). Poderes, identidades e sociedade na América portuguesa (séculos XVIXVIII). São Paulo: Alameda, 2017, p. 163-188.

SANTOS PÉREZ, J. M. Visita, residência, venalidade. As "práticas castelhanas" no Brasil de Filipe III. In: MEGIANI, A. P. T.; SILVA, K. V.; SANTOS PÉREZ, J. M. (Eds.) O Brasil na monarquia hispânica (1580-1668): novas interpretações. São Paulo: Humanitas, 2016, p. 23 37.

SARAGOÇA, L. Da "Feliz Lusitânia" aos confins da Amazônia (1615-1662). Lisboa: Edições Cosmos; Câmara Municipal de Santarém, 2000.

SOUZA, M. L. de. "Território" da divergência (e da confusão). Em torno das imprecisas fronteiras de um conceito fundamental. In: SAQUET, M. A.; SPOSITO, E. S. (Org.). Territórios e territorialidades: teorias, processos e conflitos. $2^{\mathrm{a}}$ ed. Rio de Janeiro: Consequência, 2015, p. 53-68.

VARNHAGEN, F. A. de. História Geral do Brazil. Rio de Janeiro: E. H. Laemmert, 1857, t. II. 